\title{
Oxidative Damage of Glycated Protein in the Presence of Transition Metal Ion
}

\author{
Rong-zhu Cheng, Jun Tsunehiro, Koji Uchida \\ and Shunro KAWAKISHI \\ Department of Food Science and Technology, Nagoya University, \\ Furo-cho, Chikusa-ku, Nagoya 464-01, Japan
}

Received December 28, 1990

\begin{abstract}
Glycation of proteins was induced by incubation of high concentrations of D-glucose $(1 \mathrm{M})$ and proteins $(4 \mathrm{mg} / \mathrm{ml})$ at $40^{\circ} \mathrm{C}$ for 7 days. The oxidative damage of glycated protein mediated by addition of traces of metal ion in phosphate buffer $(1 / 15 \mathrm{M}, \mathrm{pH} 7.2)$ under aerated conditions was investigated. Free amino groups (mainly $\varepsilon-\mathrm{NH}_{2}$ groups of lysine residues) of protein decreased during the glycation of protein but were regenerated in the oxidation of glycated protein induced with metal ion. Also in this process, an $\alpha$-dicarbonyl compound was generated. Glycated protein was degraded to lower molecular weight fragments in the presence of $\mathrm{Cu}$ (II) but not in the absence of $\mathrm{Cu}$ (II). Moreover, the histidine residue of protein was selectively degradated in this oxidative process. The oxidative fragmentations of glycated protein were inhibited by EDTA or catalase, but not by urea, DMSO (scavengers of hydroxy radicals) or superoxide dismutase. A possible mechanism of oxidative fragmentation of glycated protein catalyzed by the metal ion is discussed.
\end{abstract}

Glycation, also known as nonenzymatic glycosylation, is the condensation reaction between glucose and the free amino groups of protein molecules. The reactive amino groups are either $\alpha-\mathrm{NH}_{2}$ groups of protein $\mathrm{N}$-termini or $\varepsilon-\mathrm{NH}_{2}$ groups of certain lysine residues, depending on their accessibility and environment. ${ }^{1-3)}$ Glycation proceeds through a Schiff's base intermediate, follows by Amadori rearrangement to yield relatively stable ketoamine adducts of proteins. ${ }^{4,5)}$ This product is called glycated protein. The reaction up to the formation of Amadori compounds is considered to be the initial stage of the Maillard reaction. Glycation has been found both in vivo and in vitro and the relationship of glycated proteins with several diseases and aging in the human body is also known. For example, in hemoglobin, plasma protein, collagen, hair, lens, and other long-lived proteins, the levels of fructoselysine formed by glycation of lysine residues in protein have been known to increase in proportion to the degree of hyperglycemia in diabetes. ${ }^{6)}$ The oxidation of fructoselysine (FL) in phosphate buffer under aerated con- ditions generates two products, $N$-(carboxymethyl)lysine (CML) and 3-( $N$-lysino)lactic acid, and these two products have also been identified in human lens proteins, collagen, and urine. ${ }^{7-9)}$ Furthermore during the aging of lens proteins in vivo, Baynes ${ }^{10)}$ also confirmed that the $N$-(carboxymethyl)lysine (CML) rather than fructoselysine (FL) was the major age-dependent product of glycation in adult lens proteins.

On the other hand, oxygen radicals were generated from the browning solution of glucose and amino acids in the presence of copper ion and their oxidative action on protein have been investigated in detail. ${ }^{11)}$ It has been reported that the active oxygen species generated from Amadori compounds under physiological conditions induced cleavage of nucleic acid and inactivation of viruses. ${ }^{12,13)}$ Furthermore, generation of superoxide $\left(\mathrm{O}_{2}{ }^{-}\right)$ and lipid peroxidation during the oxidation of glycated polylysine in the presence of iron-ADP have also been reported recently. ${ }^{14)}$

With this background, it is considered that glycated protein may generate active oxygen 
radicals in the presence of traces of transition metal ion under physiological conditions and the radical species will oxidatively attack the protein itself to cause conformational change and structural damage. This paper is concerned with the autoxidative degradation and fragmentation of glycated protein and the oxidative damage of histidine residue in protein molecules in the presence of traces of transition metal ion under physiological conditions.

\section{Materials and Methods}

Materials. Bovine serum albumin (BSA) and chicken egg white lysozyme were purchased from Seikagaku Kogyo Co., Ltd. (Tokyo). Ovalbumin was purchased from Sigma Chemical Co. Polylysine was obtained from Peptide Institute Inc. (Osaka). Other reagents were of the best grades commercially available.

Glycation of protein. Protein $(4 \mathrm{mg} / \mathrm{ml})$ was incubated with glucose (1 M) in phosphate buffer (1/15 $\mathrm{M}, \mathrm{pH} 7.2)$ containing traces of gentamicin for 7 days at $40^{\circ} \mathrm{C}$. Excess glucose in the reaction mixture was dialyzed against distilled water at $4^{\circ} \mathrm{C}$ for 3 days and the water was changed two times a day. The dialyzate was lyophilized and analyzed. Glycated polylysine was prepared under the same reaction conditions as glycated protein. $N^{\alpha}-t$-Boc$N^{\varepsilon}$-Fructoselysine (FL) was prepared by reaction of $N^{\alpha}$ - $t$-Boc-lysine with D-glucose as described by Monnier. ${ }^{15}$

Incubation conditions. The incubation mixtures ( $10 \mathrm{ml})$ contained $0.04 \%(\mathrm{w} / \mathrm{v})$ glycated proteins and $50 \mu \mathrm{M} \mathrm{Cu}(\mathrm{H})$ in phosphate buffer $(1 / 15 \mathrm{M}, \mathrm{pH} 7.2)$. The reactions were started by adding $\mathrm{Cu}(\mathrm{II})$ at $40^{\circ} \mathrm{C}$ and stopped by the addition of an EDTA solution $(2 \%, w / v)$.

Measurement of free amino groups and $\alpha$-dicarbonyl compound. Free amino groups in proteins were measured by the TNBS method and the absorbance at $420 \mathrm{~nm}^{16}{ }^{16}$ $\alpha$-Dicarbonyl compounds were measured by the reaction with Girard-T reagent and the absorbance at $325 \mathrm{~nm} .{ }^{17}$

SDS-polyacrylamide gel electrophoresis (SDS-PAGE). SDS-PAGE using 10\% acrylamide gel was done by the method of Laemmli. ${ }^{18}$ Gel sheets were stained with a solution of $0.25 \%$ Coomassie Brilliant Blue R-250 in water-2-propanol-acetic acid $(5: 5: 1)$ and destained with $7 \%$ acetic acid containing $5 \%$ methanol.

High performance liquid chromatography (HPLC). Chromatographic measurement of glycated BSA was done by HPLC on a Develosil TSK-Gel $3000 \mathrm{SW}$ column $(7.5 \times 600 \mathrm{~mm})$. Samples were eluted at a rate of $1.0 \mathrm{ml} / \mathrm{min}$ with $1 / 15 \mathrm{M}$ phosphate buffer ( $\mathrm{pH} 7.0$ ) containing $0.1 \mathrm{M}$ $\mathrm{NaCl}$. The elution was monitored continuously by $\mathrm{UV}$ absorbance at $210 \mathrm{~nm}$.

Amino acids analyses. The reaction solutions of glycated protein and $\mathrm{Cu}(\mathrm{II})$ were dialyzed against distilled water for $2 \mathrm{hr}$ to remove metal ions and other low molecular weight products generated during the reaction and then reduced with $\mathrm{NaBH}_{4}$ for $2 \mathrm{hr}$ to prevent the decomposition of the Amadori type bond in the glycated protein by hydrolysis. The reduced solutions were treated with $6 \%$ TCA solution. The precipitated proteins were hydrolyzed in a sealed tube with $6 \mathrm{~N} \mathrm{HCl}$ at $110^{\circ} \mathrm{C}$ for $24 \mathrm{hr}$. The hydrolysates were concentrated to dryness, dissolved in a dilute $\mathrm{HCl}$ solution ( $\mathrm{pH} 2.2$ ) and then put into an amino acid analyzer (JEOL Model JLC-6AH).

\section{Results}

\section{Decomposition of glycated proteins induced with $\mathrm{Cu}(I I)$}

Glycated BSA, ovalbumin, and lysozyme were incubated in the absence or presence of $\mathrm{Cu}$ (II) in phosphate buffer $(1 / 15 \mathrm{M}, \mathrm{pH} 7.2)$ at $40^{\circ} \mathrm{C}$. The changes of free amino groups in proteins measured by the TNBS method are shown in Table I. The $\alpha$-dicarbonyl compound released from glycated proteins was measured by reaction with Girard-T reagent. This result is shown in Fig. 1. Similar to Amadori compounds prepared from glucose and amino acid, ${ }^{19)}$ glycated proteins were also degraded by the addition of $\mathrm{Cu}(\mathrm{II})$. The free amino groups of each glycated protein increased in the presence of $\mathrm{Cu}$ (II) but there were not any

Table I. The Changes in Free Amino Groups During Glycation and Oxidation of Glycated Proteins

Percentage of free amino groups $(\%)$

\begin{tabular}{lcccc} 
& $\begin{array}{c}\text { Native } \\
\text { protein }\end{array}$ & Glycated & $\begin{array}{c}\text { Glycated } \\
\text { protein } \\
24 \mathrm{hr}^{\mathrm{a}}\end{array}$ & $\begin{array}{c}\text { Glycated } \\
\text { protein }\end{array}$ \\
& Cu(II) $24 \mathrm{hr}^{b}$ \\
\hline BSA & 100 & 67 & 66 & 83 \\
Ovalbumin & 100 & 77 & 74 & 86 \\
Lysozyme & 100 & 71 & 67 & 80 \\
\hline
\end{tabular}

a Glycated protein $(0.04 \%)$ was incubated in phosphate buffer at $40^{\circ} \mathrm{C}$ for $24 \mathrm{hr}$ in the absence of $\mathrm{Cu}(\mathrm{II})$.

$b$ Glycated protein $(0.04 \%)$ was incubated in phosphate buffer at $40^{\circ} \mathrm{C}$ for $24 \mathrm{hr}$ in the presence of $0.05 \mathrm{~mm}$ Cu(II). 
changes in the absence of $\mathrm{Cu}(\mathrm{II})$ after incubation for 24 hr (Table I). The $\alpha$-dicarbonyl compound was also released from glycated proteins only in the presence of $\mathrm{Cu}$ (II) (Fig. $1)$. The major part of generated $\alpha$-dicarbonyl compounds was estimated to be D-glucosone, similar to the autoxidation of Amadori compounds induced with $\mathrm{Cu}(\mathrm{II}),{ }^{19)}$ but it was

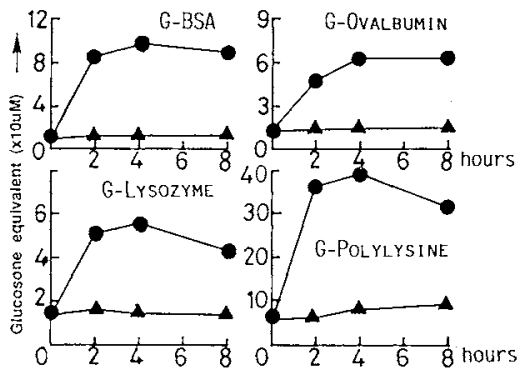

Fig. 1. Formation of $\alpha$-Dicarbonyl Compounds in Glycated Protein-Cu(II) System.

The reaction mixtures of $0.04 \%$ glycated protein in phosphate buffer (1/15 M, pH 7.2) were incubated in the presence $(0.05 \mathrm{~mm})$ and absence of cupric sulfate at $40^{\circ} \mathrm{C}$. The mixtures were reacted with Girard- $T$ reagent and the absorbance were measured at $325 \mathrm{~nm}$. The quantity of $\alpha$-dicarbonyl compounds was calculated as glucosone.

- - glycated protein/Cu(II) system; - $\mathbf{-}-$, glycated protein only.

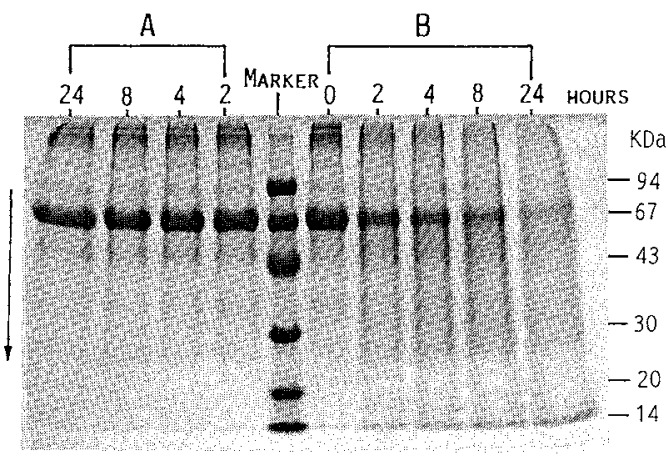

Fig. 2. SDS-Polyacrylamide Gel Electrophoresis of the Glycated Protein in the Presence (B) and Absence (A) of $\mathrm{Cu}(\mathrm{II})$.

The reactions were carried out at $40^{\circ} \mathrm{C}$, the mixtures contained $0.04 \%$ glycated bovine serum albumin and $0.05 \mathrm{~mm}$ cupric sulfate in phosphate buffer (pH 7.2). Each protion $(0.5 \mathrm{ml})$ of the reaction mixtures was sampling on time course $(0,2,4,8$, and $24 \mathrm{hr})$ and treated with $0.5 \mathrm{ml}$ of TCA solution (12\%) for $24 \mathrm{hr}$ at $4^{\circ} \mathrm{C}$ and the precipitates were submitted to SDS-PAGE. not identified in the glycated protein- $\mathrm{Cu}(\mathrm{II})$ system.

\section{Oxidative damage of glycated bovine serum albumin induced with $\mathrm{Cu}(\mathrm{II})$}

Time-dependent alteration of glycated BSA during incubation with or without $\mathrm{Cu}(\mathrm{II})$ was examined by SDS-PAGE as shown in Fig. 2. The major band of glycated BSA (about $67 \mathrm{kDa})$ gradually disappeared and the oxidized lower molecular fragments appeared under $14 \mathrm{kDa}$ in the presence of $\mathrm{Cu}$ (II). After incubation for $24 \mathrm{hr}$, more than $80 \%$ of the glycated BSA was degraded (measured by HPLC, data not shown). However, no changes in the glycated BSA were observed in the absence of $\mathrm{Cu}$ (II). On the other hand, glycated ovalbumin and lysozyme were also degraded only in the presence of $\mathrm{Cu}(\mathrm{II})$. To investigate the site-specific damage of amino acid residues during the oxidation of glycated protein induced with $\mathrm{Cu}(\mathrm{II})$, the amino acids were analyzed. Glycated BSA, ovalbumin, lysozyme were incubated with $\mathrm{Cu}(\mathrm{II})$ in phosphate buffer

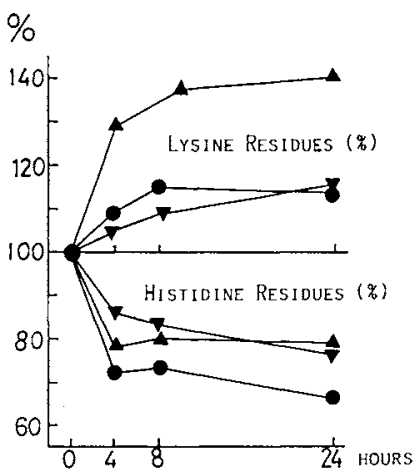

Fig. 3. Time-Dependent Changes of Histidine and Lysine Residues in Glycated Protein/Cu(II) Reaction System.

The reaction mixtures contained $0.04 \%$ glycated protein and $0.05 \mathrm{~mm}$ cupric sulfate were incubated in phosphate buffer solution $(\mathrm{pH} 7.2)$ at $40^{\circ} \mathrm{C}$. Each portion $(2.5 \mathrm{ml})$ of the reaction mixtures was sampling on time course $(0,4$, 8 , and $24 \mathrm{hr}$ ), dialyzed, reduced with $\mathrm{NaBH}_{4}$ and then, treated with TCA solution $(12 \%)$ for $24 \mathrm{hr}$ at $4^{\circ} \mathrm{C}$. The precipitated samples were submitted to amino acids analyses.

- - , glycated BSA/Cu(II);- - - - , glycated ovalbumin/ $\mathrm{Cu}(\mathrm{II}) ;-\boldsymbol{\Lambda}-$, glycated lysozyme/Cu(II). 
$(1 / 15 \mathrm{M}, \mathrm{pH} 7.2)$ at $40^{\circ} \mathrm{C}$. Samples were taken in time course and the proteins were precipitated by $6 \%$ TCA solution. Based on the amino acid analyses, only histidine and lysine residues changed with the oxidation of glycated proteins induced with $\mathrm{Cu}(\mathrm{II})$, while the other amino acids did not have any changes under the same conditions. Figure 3 shows the time-dependent changes in histidine and lysine residues of glycated proteins during the oxidation induced with $\mathrm{Cu}(\mathrm{II})$. According to incubation time, lysine residues increased and histidine residues decreased gradually.

Furthermore, to clarify the changes of lysine residue in glycated protein, $N^{\alpha}-t$-Boc- $N^{\varepsilon}$ fructoselysine (FL) and glycated polylysine prepared from polylysine and glucose were used. Fructoselysine and glycated polylysine were incubated with the same reaction conditions mentioned above and followed by the reduction with $\mathrm{NaBH}_{4}$ for $2 \mathrm{hr}$. The reduced sample prepared from the reaction mixture of $N^{\alpha}$ - $t$-Boc- $N^{\varepsilon}$-fructoselysine (FL) was concentrated and then the Boc-group was removed by reaction with $\mathrm{BF}_{3}\left(\mathrm{CH}_{3} \mathrm{CH}_{2} \mathrm{O}\right)_{2} /$ $\mathrm{CH}_{3} \mathrm{COOH}$ for $30 \mathrm{~min}$ at room temperature ${ }^{20}$ )

Table II. Amino Acids Analyses of Oxidized $N^{e}$-Fructoselysine ANd GlyCated POLyLysine ${ }^{a}$

\begin{tabular}{|c|c|c|c|}
\hline & \multicolumn{3}{|c|}{ Area percent $(\%)$} \\
\hline & Lysine & $\begin{array}{l}\text { Amadori } \\
\text { comp. }\end{array}$ & $\mathrm{NH}_{4} \mathrm{OH}$ \\
\hline Polylysine & 97.8 & 0 & 1.2 \\
\hline $\begin{array}{l}\text { Glycated } \\
\text { polylysine }\end{array}$ & 51.9 & 33.5 & 4.0 \\
\hline $\begin{array}{l}\text { Glycated } \\
\text { polylysine } \\
+\mathrm{Cu}(\mathrm{II})^{b}\end{array}$ & 77.2 & 2.4 & 7.3 \\
\hline Fructoselysine & 0 & 86.5 & 1.2 \\
\hline $\begin{array}{l}\text { Fructoselysine } \\
+\mathrm{Cu}(\mathrm{II})^{c}\end{array}$ & 66 & 7.9 & 2.6 \\
\hline
\end{tabular}

a All samples were reduced with $\mathrm{NaBH}_{4}$ for $2 \mathrm{hr}$ before hydrolysis.

$b$ The reaction was done at $40^{\circ} \mathrm{C}$ for $24 \mathrm{hr}$, the solutions containing $0.04 \%$ glycated polylysine and $0.05 \mathrm{~mm}$ $\mathrm{Cu}(\mathrm{II})$ in phosphate buffer.

c The reaction was also done at $40^{\circ} \mathrm{C}$ for $24 \mathrm{hr}$, the solutions containing $5 \mathrm{~mm}$ fructoselysine and $0.05 \mathrm{~mm}$ $\mathrm{Cu}(\mathrm{II})$ in phosphate buffer. and concentrated again. The reduced sample was dissolved in dilute $\mathrm{HCl}(\mathrm{pH} 2.2)$ and then analyzed using an amino acid analyzer. For glycated polylysine, the reduced sample was hydrolyzed by the same procedure with the glycated proteins. These data (Table II) showed that fructoselysine and glycated polylysine were also oxidatively degraded by the addition of $\mathrm{Cu}(\mathrm{II})$. After incubation with $\mathrm{Cu}(\mathrm{II})$ for $24 \mathrm{hr}$, most of the Amadori compounds were decomposed and lysine residues were regenerated similarly to the glycated proteins.

From these results, it shows that in the presence of $\mathrm{Cu}(\mathrm{H})$, glycated proteins were decomposed mainly at the site of $\varepsilon$-amino groups of lysine residues, releasing the dicarbonyl compound, and then caused selective oxidative degradation of its histidine residues (Fig. 3).

\section{Effects of metal ions on the oxidation of glycated $B S A$}

To evaluate the effects of $\mathrm{Cu}(\mathrm{II})$ on the specificity of oxidative damage of glycated protein, the effects of other metal ions, such as $\mathrm{Fe}(\mathrm{II}), \mathrm{Fe}(\mathrm{III}), \mathrm{Co}(\mathrm{II}), \mathrm{Mn}(\mathrm{II}), \mathrm{Mg}(\mathrm{II})$, and $\mathrm{Ca}(\mathrm{II})$ were examined (Fig. 4). Among of them,

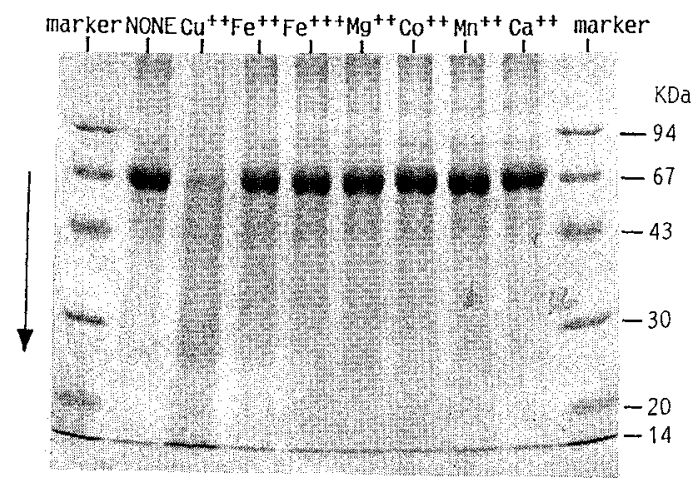

Fig. 4. Effects of Metal Ions on Oxidation of Glycated Bovine Serum Albumin by SDS-Polyacrylamide Gel Electrophoresis

The reactions were carried out at $40^{\circ} \mathrm{C}$ for $24 \mathrm{hr}$ and the mixtures contained $0.04 \%$ glycated bovine serum albumin and $0.05 \mathrm{~mm}$ of each kind of metal ion in phosphate buffer. Ferric and ferrous ions were solubilizd to EDTA $(0.2 \mathrm{~mm})$-phosphate buffer solution prior to addition into the reaction mixture. After incubation for $24 \mathrm{hr}$, each portion of the reaction mixtures $(0.5 \mathrm{ml})$ was followed by the same procedure in Fig. 2. 
Table III. EFFECTS OF INHIBITORS ON OXIDATION OF Glycated Bovine Serum Albumin with Cu(II) System ${ }^{a}$

\begin{tabular}{lcc}
\hline Inhibitors & Conc. $^{b}$ & $(\%)$ Inhibition $^{c}$ \\
\hline None & - & 0 \\
EDTA & $10 \mathrm{~mm}$ & 79.3 \\
Urea & $10 \mathrm{~mm}$ & 20.7 \\
DMSO & $10 \mathrm{~mm}$ & 10.3 \\
SOD & 500 units $/ \mathrm{ml}$ & 1.7 \\
Catalase & 500 units $/ \mathrm{ml}$ & 82.8 \\
\hline
\end{tabular}

a The reactions were done at $40^{\circ} \mathrm{C}$ for $24 \mathrm{hr}$, the solutions containing $0.04 \%$ glycated bovine serum albumin and $0.05 \mathrm{~mm} \mathrm{Cu(II)}$ in phosphate buffer (1/15 M, pH 7.2). Oxidation of the protein was detected by HPLC on a TSK-GEL G3000SW column.

$b$ All concentrations shown are final reaction concentrations.

c The percentage of inhibition is calculated as follow:

$$
(\%) \text { inhibition }=100-\frac{A-X}{A-B} \times 100
$$

$A$ : the peak height of glycated BSA $(0.04 \%)$ in phosphate buffer on 24 hr incubation.

$B$ : the peak height of glycated BSA $(0.04 \%)$ and $0.05 \mathrm{~mm} \mathrm{Cu}(\mathrm{II})$ in phosphate buffer on $24 \mathrm{hr}$ incubation.

$X$ : the peak height of $[B+$ inhibitor $]$ system.

$\mathrm{Cu}(\mathrm{II})$ had stronger activity for oxidative damage of glycated BSA. By HPLC, about $80 \%$ of the glycated BSA was cleaved with $\mathrm{Cu}(\mathrm{II})$ and only about $15 \%$ by $\mathrm{Fe}(\mathrm{II}) / \mathrm{EDTA}$ or Fe(III)/EDTA. Other metal ions had little activity toward the oxidation of glycated BSA.

\section{Effects of several inhibitors on the fragmentation} of glycated BSA induced with $\mathrm{Cu}(\mathrm{II})$

Since these reactions might arise from some oxygen radicals formed through the interaction in the glycated protein $/ \mathrm{Cu}(\mathrm{II}) / \mathrm{O}_{2}$ system like that of the ascorbate $/ \mathrm{Cu}(\mathrm{II}) / \mathrm{O}_{2}$ system, a series of hydroxyl radical scavengers, enzymes relating to the degradation of active oxygen and chelating agent of metal ion were added to this sytem. As shown in Table III, catalase and EDTA completely depressed the oxidative degradation of glycated BSA induced with $\mathrm{Cu}(\mathrm{II})$, but the hydroxyl radical scavengers (dimethyl sulfoxide and urea) and superoxide dismutase (SOD) only weakly suppressed the oxidative reaction.

\section{Discussion}

Glucose reacts with $\varepsilon$-amino groups of lysine residues on proteins via Schiff's base to form glycated proteins having an Amadori compound structure. In the preparation of glycated proteins, lysine residues on proteins decreased in the reaction with glucose. During the oxidation of glycated proteins, free amino groups on proteins increased (Table I) and the $\alpha$-dicarbonyl compound was formed (Fig. 1) in the presence of $\mathrm{Cu}(\mathrm{II})$ but not in the absence of $\mathrm{Cu}(\mathrm{II})$. Also, only in the presence of $\mathrm{Cu}$ (II), the oxidative fragmentation of glycated BSA was observed and its histidine residues were markedly degraded (Fig. 3) while the lysine residues gradually increased (Fig. 3, Table II) during oxidation. Therefore these facts suggested that the glucose moieties bound to lysine residues of protein were oxidatively eliminated to form the free $\varepsilon$-amino group and $D$ glucosone by oxidative reaction.

Wolff and Dean reported that when protein were exposed to glucose, the cleavage and conformation changes of protein arose depending on the formation of hydroxyl radicals by glucose-autoxidation and ketoaldehyde was produced as an autoxidation-derived product of the glucose moiety. ${ }^{21-23)}$ Furthermore, we also demonstrated the formation of the $\alpha$-dicarbonyl compound by oxidative degradation of the linkage between the $\varepsilon$-amino groups of lysine residues and glucose (Table I, Figs. 1 and 3). And the damage of protein, its fragmentation and selective degradation of histidine residues might be dependent upon some oxygen radicals or copper oxygen complex, similar to the ascorbate-Cu(II) system. $^{24,25)}$

On the other hand, Nakano reported that the glycated polylysine-Fe(III)/ADP system produced $\mathrm{O}_{2}{ }^{-}$under physiological conditions and induced lipid peroxidation. This peroxidation reaction was slightly inhibited by $0.5 \mu \mathrm{M}$ SOD but not by catalase. But in our glycated 


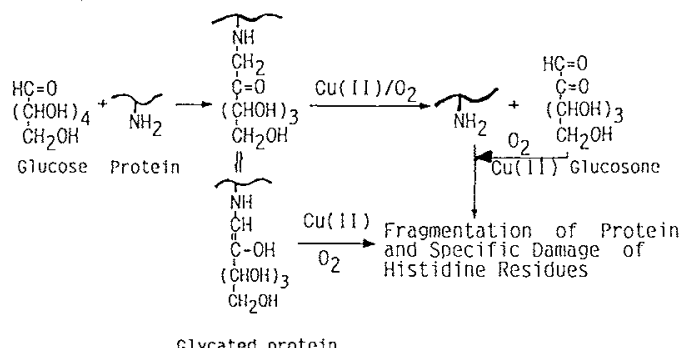

Glycated protein

Fig. 5. A Possible Mechanism of Metal Ion Catalyzed Oxidative Fragmentation of Glycated Protein.

protein $\mathrm{Cu}(\mathrm{II})$ system, the oxidative fragmentation of protein was inhibited by a metalchelating agent (EDTA) and catalase (about $80 \%$ ), but not by SOD and some radical scavengers (Table III). These results suggest that the oxidative reaction perhaps operates at a specific site in glycated protein. $\mathrm{O}_{2}{ }^{-}$was generated via the Amadori compound-metal ion complex ${ }^{14)}$ or the glucosone(ketoaldehyde)-Cu(II) reaction similar to ascorbate-$\mathrm{Cu}$ (II) system, and then transformed quickly to $\mathrm{H}_{2} \mathrm{O}_{2}$. Some active oxygen species must be generated at the site where the complex of protein- $\mathrm{Cu}(\mathrm{II})$-Amadori type linkages was formed, and then, site-specific fragmentation of protein (Fig. 2) and the degradation of histidine residues (Fig. 3) might occur, but the active oxygen species generated in this system have not been identified.

From these results, a possible mechanism of oxidative damage of glycated protein is summarized in Fig. 5. Through the oxidative fragmentation of the glycated protein and the selective degradation of histidine residue, $\alpha$-dicarbonyl compounds containing glucosone were also decomposed simultaneously, but their decomposed products have not yet been detected. However, histidine residues must be decomposed through 2-oxohistidine as in the ascorbate- $\mathrm{Cu}(\mathrm{II})$ system. ${ }^{24,25)}$

\section{References}

1) H. F. Bunn, R. Shapiro, M. McManus, L. Garrick, M. I. McDonald, M. Gallop and K. H. Gabbay, J.
Biol. Chem., 254, 3892 (1979).

2) C. M. Gundberg, M. Anderson, I. Dickson and P. Gallop, J. Biol. Chem., 261, 14557 (1986).

3) R. L. Garlick and J. S. Mazer, J. Biol. Chem., 258, 6142 (1983)

4) H. S. Isbell and H. Frush, J. Org. Chem., 23, 1309 (1958).

5) A. Gottschalk, in "The Glycoprotein," Part A, Elsevier, Amsterdam, 1972, pp. 141157.

6) L. Kennedy and J. W. Baynes, Diabetologia, 27, 92 (1984).

7) M. U. Ahmed, S. R. Thorpe and J. W. Baynes, $J$ Biol. Chem., 261, 4889 (1986).

8) M. U. Ahmed, J. A. Dunn, M. D. Walla, S. R. Thorpe and J. W. Baynes, J. Biol. Chem., 263, 8816 (1988).

9) J. W. Baynes, M. U. Ahmed, C. I. Fisher, C. J. Hull, T. A. Lehman, N. G. Watkins and S. R. Thorpe, Dev. Food Sci., 13, 421 (1986).

10) J. A. Dunn, J. S. Patrick, S. R. Thorpe and J. W. Baynes, Biochem., 28, 9464 (1989).

11) S. Kawakishi, Y. Okawa and K. Uchida, J. Agric. Food Chem., 38, 13 (1990).

12) N. Kashimura, J. Morita, K. Sugiura, S. Nishikawa and Z. Kumazawa, in "The Role of Oxygen in Chemistry and Biochemistry," ed. by W. Ando and Y. Morooka, Elsevier, Amsterdam, 1988, pp. 483488.

13) N. Kashimura, J. Morita, J. Sato, Z. Kumazawa, S. Nishikawa, S. Ito, Y. Koma and M. Komada, in "Amino-Carbonyl Reaction in Food and Biological System," ed. by M. Namiki and H. Kato, ElsevierKodansha, Japan, 1986, pp. 401-410.

14) T. Sakurai, K. Sugioka and M. Nakano, Biochim. Biophys. Acta, 1043, 27 (1990).

15) F. G. Njoroge, A. A. Fernandes and V. M. Monnier, J. Biol. Chem., 263, 10646 (1988).

16) T. Okuyama and H. Kasai, Protein, Nucleic Acid and Enzyme, 18, 1153 (1973).

17) R. E. J. Mitchel and H. C. Birnboim, Anal. Biochem., 81, 47 (1977).

18) U. K. Laemmli, Nature, 227, 680 (1970)

19) S. Kawakishi, J. Tsunehiro and K. Uchida, Carbohydrate Research, 211, 167 (1991).

20) V. E. Schnabel, H. Klostermeyer and U. H. Berndt, Ann. Chem., 749, 90 (1971)

21) S. P. Wolff and R. T. Dean, Biochem. J., 245, 243 (1987).

22) S. P. Wolff and R. T. Dean, Bioelectrochem Bioenerg., 18, 283 (1987).

23) J. V. Hunt, R. T. Dean and S. P. Wolff, Biochem. $J, 256,205$ (1988).

24) K. Uchida and S. Kawakishi, Bioorganic Chem., 17, 330 (1989).

25) K. Uchida and S. Kawakishi, J. Agric. Food Chem., 37, 897 (1989). 